\title{
THE CHAUVENET PRIZE FOR MATHEMATICAL EXPOSITION
}

In March, 1925, President J. L. Coolidge proposed that the Mathematical Association of America establish a prize for special merit in mathematical exposition. The proposition was sanctioned by mail vote of the Trustees and a committee consisting of Professors A. J. Kempner, Chairman, Louise D. Cummings and D. R. Curtiss was appointed to formulate the details. This committee presented a report at the Ithaca meeting which in somewhat modified form, was adopted by the Trustees. The substance of the report is as follows.

The committee believe that the proposed prize will exert a desirable influence on the production of high-grade exposisitory articles. They adopted the name suggested by President Coolidge, namely, "The Chauvenet Prize for Mathematical Exposition." For a study of the life and influence of William Chauvenet, 1820-1870, Professor of mathematics in the U. S. Navy, 1847-1859, President of the Academic Board of the Navy, 1847-1850, Professor of mathematics and natural philosophy at Washington University, St. Louis, Mo., 18591869 , author of many works and treatises, they refer to an article by Professor W. H. Roever, in Washington University Studies, Vol. 12, Scientific Series, No. 2, 1925.

The Chauvenet Prize is to be awarded every five years for the best article of an expository character dealing with some mathematical topic, written by a member of the Mathematical Association of America and published in English in a journal during the five calendar years preceding the award. This prize will not be awarded for books, even though a large portion of mathematical books are mainly or completely expository in character, such as textbooks. They bring their own reward in the form of royalties.

The amount of the prize was fixed at one hundred dollars, an amount which the committee deemed sufficiently large to 
be attractive apart from the honor of the award. The cash for the first award has been provided by a friend of the Association. Thereafter, it will be supplied from the Association treasury, one-fifth of the amount being set aside each year for the purpose.

The first award is to be made at the annual meeting in December, 1925, covering the five-year period ending with the calendar year 1924.*

It is provided that the award shall be determined at each quinquennial period by a scrutinizing committee of three to be appointed by the president of the Association and that this committee should be restricted as little as possible, aside from the specifications mentioned in the foregoing paragraphs. President Coolidge appointed the scrutinizing committee for the first award as follows: Professors W. C. Graustein, Anna J. Pell-Wheeler, E. B. Van Vleck (chairman).

\section{THE INTERNATIONAL CONFERENCE FOR THE USE OF ESPERANTO IN SCIENCE $\dagger$}

The international conference on the use of Esperanto in science, held in Paris on May 14, 15, 16, 1925, simultaneously with the conference on its use in commerce, signalizes the restoration of this international movement, which was stopped almost completely during the war. Among the members of the French Academy of Sciences who lent their support to this conference are the physiologist Richet, the physicists

* The first award of this prize was made since this article was written, at the Kansas City Meeting of the Association. The recipient was Professor G. A. Bliss, of the University of Chicago. The paper which was the basis of the award was his paper Algebraic functions and their divisors, published in the Annals of Mathematics for September and December, 1924.

† A report prepared by Professor M. Fréchet, who attended the Congress as the official delegate of this Society. 